\title{
Synthesis of New 2-Substituted Phenyl-1H-Indoles via Fischer Indole Reaction
}

\author{
SHAHID SHAIKH ${ }^{\mathrm{a}}$, NAZIABEGUM SHAIKH ${ }^{\mathrm{b}}$, \\ MOHAMMAD ZAMIR ${ }^{\mathrm{a}}$, S. D. SALUNKE ${ }^{\mathrm{b}}$ and M. A. BASEER ${ }^{\mathrm{a}^{*}}$ \\ ${ }^{a}$ Organic Chemistry Research Laboratory, Yeshwant Mahavidyalaya, \\ Nanded-431602, Maharashtra, India \\ ${ }^{\mathrm{b}}$ Research Centre in Chemistry, Rajarshi Shahu Mahavidyalaya, \\ Latur-413512, Maharashtra, India \\ baseer_nanded@yahoo.com
}

Received 25 October 2012 / Accepted 12 November 2012

\begin{abstract}
A series of new 2-substituted aryl- $1 \mathrm{H}$-indole derivatives have been synthesized by reacting phenyl hydrazine with various substituted acetophenones in presence of sulfuric acid in good to excellent yield. This transformation is based on Fischer indole reaction.
\end{abstract}

Keywords: 2-Substituted aryl-1H-indoles, Phenyl hydrazine, Substituted acetophenones, Fischer Indole reaction

\section{Introduction}

In the vast heterocyclic structural space, the indole nucleus is probably most widely distributed heterocyclic ring system found in nature ${ }^{1}$ and occupies a position of major importance due to its therapeutic and pharmacological activities ${ }^{2-3}$. Indole derivatives are used as neuroprotective agent affecting oxidative stress ${ }^{4}$, neurotransmitter serotonin ${ }^{5}$ (5-HT 5-hydroxytriptamine) involved in various physiological functions such as appetite, sleep, body temperature, indolodioxane is found to be active hypertensive agent ${ }^{6}$, INF55 is an inhibitor of NorA efflux pump in the human pathogenic bacterium staphylococcus aureus ${ }^{7}$. Different indole derivatives like tryptans are used as antimigrain and anti-inflammatory ${ }^{8-9}$, anticonvulsant ${ }^{10}$, antimicrobial ${ }^{11}$, antimalarial ${ }^{12}$ and anticancer ${ }^{13}$. During the past 100 years, considerable attention had been directed towards the synthesis and functionalization of compounds containing the indole skeleton. A variety of synthetic methods were developed, the oldest and classical methods used for indole synthesis include the Fischer indole synthesis ${ }^{14}$, Bischler synthesis ${ }^{15}$, Madelung cyclization of $N$-acyl-o-toluidines ${ }^{16}$ and recently various transition metal catalyzed transformation are developed ${ }^{17}$. 
Despite the progress achieved continual emergence of novel biologically active indole containing natural products promote the development of new 2,3-substituted indoles ${ }^{18}$. While indole that have functional substituent at C-2 and C-3 position are capable of binding to many receptors with high affinity especially for electron withdrawing substituent at C-2 position $^{19-20}$. Herein we report the results on synthesis of new 2-substituted phenyl- $1 \mathrm{H}$ indole derivatives via sulfuric acid catalyzed Fischer indole reaction.

\section{Experimental}

IR Specrta were recorded on Shimadzu FT-IR Spectrometer using potassium bromide pellets, ${ }^{1} \mathrm{H}$ NMR was determined on a Bruker Avance II 400 NMR Spectrometer against TMS as internal standerd. Mass spectrs were recorded on EI-technique on Shimadzu Qt 2010 plus GCMS. Purity of compounds were checked by thin layer chromatographic technique.

\section{General procedure for the synthesis of Fischer indole reaction 3(a-h)}

A mixture of substituted acetophenone $(1 \mathrm{mmol})$ and phenyl hydrazine $(1 \mathrm{mmol})$ was refluxed in ethanol for 2-4 hours. The hydrazones formed were poured into sulfuric acid. The reaction mixture was stirred and heated for additional 25-30 minutes. After completion of reaction (monitored by TLC), the reaction mixture was added to ice cold water. The solid product obtained was filtered, dried and recrystllised from ethanol to get the product with high purity.

\section{Spectral Data}

4-Chloro-6 (1H-indole-2yl)-2-iodo-3-methylphenol (3a)

IR( $\left(\mathrm{cm}^{-1}, \mathrm{KBr}\right)$ : 3406,3329,1600,1492,1442,1249,1076,786. ${ }^{1} \mathrm{H}$ NMR $\left(\mathrm{CDCl}_{3}, \delta, \mathrm{ppm}\right): 2.28$ (s,3H, $\left.\mathrm{CH}_{3}\right)$; 6.97 (m,1H,Ar-H); 7.28-7.35 (m,4H,Ar-H); $7.66\left(\mathrm{~s}, 1 \mathrm{H}, \mathrm{C}^{3} \mathrm{H}\right) ; 13.5(\mathrm{~s}, 1 \mathrm{H}, \mathrm{N}-\mathrm{H})$. Mass $m / z: 386(\mathrm{M}+2)$.

\section{2-(1H-indol-2yl)-4,6-diiodophenol (3d)}

IR( $\left.\mathrm{cm}^{-1}, \mathrm{KBr}\right): 3340,1600,1496,1435,1249,1076 .{ }^{1} \mathrm{H}$ NMR(CDCl $\left., \delta, \mathrm{ppm}\right): 6.86-6.90$ (m,2H, Ar-H); 7.09-7.11(d,2H,Ar-H); 7.26-7.30 (m,2H,Ar-H); $7.42\left(\mathrm{~s}, 1 \mathrm{H}, \mathrm{C}^{3} \mathrm{H}\right) ; 9.62$ (s,1H,OH); $13.9(\mathrm{~s}, 1 \mathrm{H}, \mathrm{N}-\mathrm{H})$. Mass $\mathrm{m} / \mathrm{z}:$ 461( $\left.\mathrm{M}^{+}\right)$.

\section{4-Chloro-2-(1H-indole-2yl)-6-iodophenol (3h)}

IR( $\left.\mathrm{cm}^{-1}, \mathrm{KBr}\right): 3430,3340,1600,1460,1440,1249,1076 .{ }^{1} \mathrm{H}$ NMR $\left(\mathrm{CDCl}_{3}, \delta, \mathrm{ppm}\right): 6.86-6.90$ (m,1H,Ar-H); 7.08-7.11 (d,2H,Ar-H); 7.27-7.31 (m,2H,Ar-H); 7.48-7.49 (d,1H,Ar-H); 7.61 (s,1H,C $\left.\mathrm{C}^{3} \mathrm{H}\right) ; 9.66$ (s,1H,O-H); $14.0(\mathrm{~s}, 1 \mathrm{H}, \mathrm{N}-\mathrm{H})$.

\section{Results and Discussion}

The use of different ketones for indole synthesis have been investigated, but so far ortho/meta/para substituted acetophenones on Fischer indole synthesis have not been reported. Therefore the presence of bromo, chloro, hydroxyl, iodo and methyl groups in different position of benzene ring of the acetophenones and the use of phenyl hydrazine resulted in a new synthesis of indole derivatives with significantly high yield.

Initially the reaction condition was optimized by the investigation of model reaction of phenyl hydrazine 1a and 5-chloro-2-hydroxy-3-iodo-4-methyl acetophenone 2a using sulfuric acid in ethanol solvent at reflux temperature to obtain desired product (3a) (Scheme 1). With same reaction condition, several substituted acetophenones 2(a-h) were treated with phenyl hydrazine and the results are summarized in Table 1. 
<smiles>NNc1ccccc1</smiles>
$1 \mathrm{a}$<smiles>[R4]c1cc(C(C)=O)c([R])c([R2])c1[R4]</smiles>

2a-h<smiles>[R]c1cc(-c2cc3ccccc3[nH]2)c([R1])c([R])c1[R3]</smiles>

3a-h

Scheme 1

Table 1. Synthesis of substituted 2-aryl- $1 H$-indoles

(n)


All the reaction was complete in less than four hours. Both the electron donating and electron withdrawing substituent on precursors acetophenones afforeded the corresponding indole derivatives in good to excellent yields. The structures of all the compounds were established from IR, ${ }^{1} \mathrm{H}$ NMR and mass analysis. The ${ }^{1} \mathrm{HNMR}$ spectra of $\mathbf{3 a}$, $\mathbf{3 d}$ and $\mathbf{3 h}$ showed a characteristic singlet due to $\mathrm{C}^{3}-\mathrm{H}$ proton around $\delta$ 7.4-7.6 $\mathrm{ppm}$. We also noted the upfield-shifted proton N-H to $\delta 13-14 \mathrm{ppm}$ and the disappearance of the singlet of methyl group during Fischer indolization. The accepted mechanism for Fischer synthesis has three steps. (a) toutomeric conversion of phenyl hydrazone to enehydrazine (b) carbon-carbon double bond formation (c) cyclization with ammonia elimination and finellly indole synthesis (Figure 1).

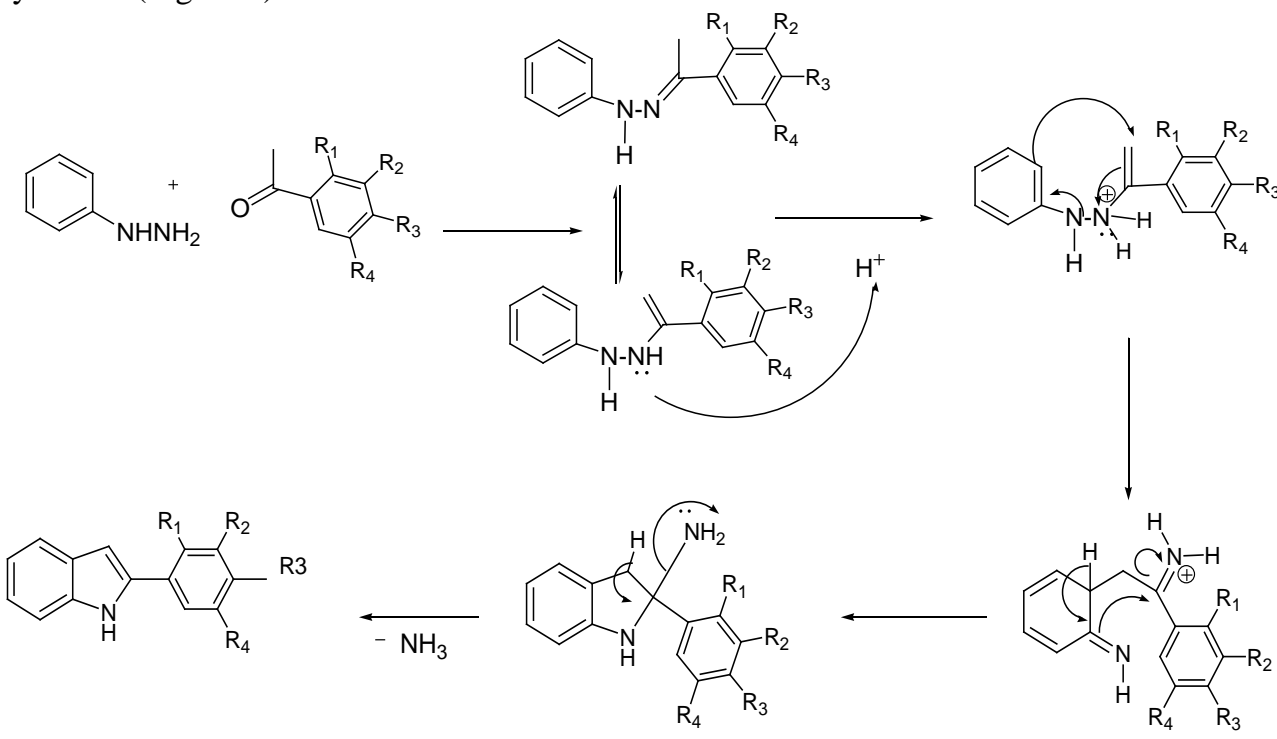

Figure 1. Possible mechanism for Fischer indole synthesis

\section{Conclusion}

In this work, we report the Fischer indolization of phenyl hydrazine with substituted acetophenones leading to new substituted 2-aryl- $1 \mathrm{H}$-indoles bearing either electron withdrawing or donating groups at ortho/meta/para position of C-2 substituted phenyl ring of the product. The structures of the product were established with spectroscopic data of proton NMR, Mass and IR.

\section{Acknowledgement}

The authors are thankful to the UGC for major Research Grant Assistance and Principal Yeshwant Mahavidyalaya, Nanded for providing all necessary research facilities to carry out this work.

\section{References}

1. Kuethe J T, Wong A, Qu C, Smitrovich J, Davis I W and Hughes D L, J Org Chem., 2005, 70, 504.

2. Takayama H, Tsutsumi S I, Kitajima M, Santiarworn D, Liawrungrath B and Aimi N, Chem Pharm Bull., 2003, 51, 232. 
3. Ihara M and Fukumoto K, Nat Prod Rep., 1995, 277.

4. Stolc S, Snirc V, Majecova M, Gasparova Z, Gajdosikova A and Stvrtina S, Cell Mol Neurobiol., 2006, 26, 1493.

5. Paul R B, Bang C C, Thomas R S and Derron R S, J Org Chem., 1997, 62, 9192.

6. $\quad$ Chae J B and Buchwald S L, J Org Chem., 2004, 69, 3336-3339.

7. Markham P N, Westhaus E, Klyachko K, Johnson M E and Neyfakh A A, Antimicrob Agent Chemother., 1999, 43(10), 2404-2408.

8. Castro J L and Matassa V G, Trtrahedron Lett., 1993, 34, 4705 and reference cited therein.

9. Bischoff H, Dittrich-Wengenroth E, Wuttke M, Heckroth H, Thielemann W, Woltering M and Otteneder M, PCT Int Appl., WO 2004005253.

10. Archana P, Rani K, Bajaj V K, Srivastava R, Chandra Kumar A and Forsch A, Drug Res., 2003, 55, 301.

11. Sinha D, Tiwari A K, Singh S, Shukl G, Mishra P, Chndra H and Mishra A K, Eur J Med Chem., 2008, 43(1), 160-165.

12. Bhattacharji A K, Hartell M G, Nichols D A, Hicks R P, Stanton B, van Hamont J E and Milhous W K, Eur J Med Chem., 2004, 39(1), 59-67.

13. Prudhomme M, Eur J Med Chem., 2003, 38(2), 123-140.

14. (a) Fischer E and Jourdan F, Ber.,1883, 16, 2241-2245; (b) Robbinson B, Chem Rev., 1969, 69, 227-250.

15. Varkade P E and Lieste J, Recl Trav Chim des Pays-Bas., 1946, 65(12), 912-918.

16. Madelung W, Chem Ber., 1912, 45, 1128.

17. (a) Humphrey G R and Kuethe J T, Chem Rev., 2006, 106, 2875. (b) Cacchi S and Fabrizi G, Chem Rev., 2005, 105, 2873.

18. (a) Arcadi A, Cianci R, Ferrara G and Merinelli F, Tetrahedron, 2010, 66, 2378;

(b) Chiba S, Zhang L, Sanjaya S and Ang G Y, Tetrahedron, 2010, 66(30), 5692-5700.

19. Mor M, Spadoni G, Giacomo B D, Diamantini G, Bedini A, Tarzia G, Plazzi P V, Rivara S, Nonno R, Lucini V, Pannacci M, Fraschini F and Stankov B M, Biorg Med Chem., 2001, 9, 1045-1057.

20. Horton D A, Bourne G T and Smythe M L, Chem Rev., 2003, 103(3), 893-930. 